\title{
Epidemiological and genetic investigations of human-to- human transmission of zoonotic influenza viruses
}

S Herfst ${ }^{1}$, R Fouchier (r.fouchier@erasmusmc.nl) ${ }^{1}$

1. Department of Viroscience, Postgraduate School of Molecular Medicine, Erasmus Medical Center, Rotterdam, the Netherlands

Citation style for this article:

Herfst S, Fouchier R. Epidemiological and genetic investigations of human-to-human transmission of zoonotic influenza viruses. Euro Surveill.

2014;19(25): $\mathrm{pii}=20840$. Available online: http://www.eurosurveillance.org/ViewArticle.aspx?Articleld=20840

Article submitted on 22 June 2014 / published on 26 June 2014

In September 2013, leptospirosis was diagnosed in two Spanish travellers returning from Thailand. The first case walked in floodwater in the Phi Phi Islands in pouring rain: 20 days later he presented with fever and acute hepatitis. The second presented with fever and renal failure 17 days after visiting the islands. These cases remind clinicians to consider leptospirosis in febrile patients with a history of contact with flood or fresh water while travelling to tropical countries.
Of the over 1,400 species of infectious organisms known to be pathogenic to humans, $60 \%$ are zoonotic, i.e. transmissible from animals to humans [1]. We therefore continuously face the threat of newly emerging pathogens with a major health impact. In the last decade, viral zoonoses have resulted in numerous human cases of infection with e.g. influenza A viruses, Ebola virus, Nipah virus, Hendra virus, severe acute respiratory syndrome (SARS) coronavirus, and Middle-East

\section{FIGURE}

Wild aquatic birds and bats are thought to be the reservoir for many virus families in nature

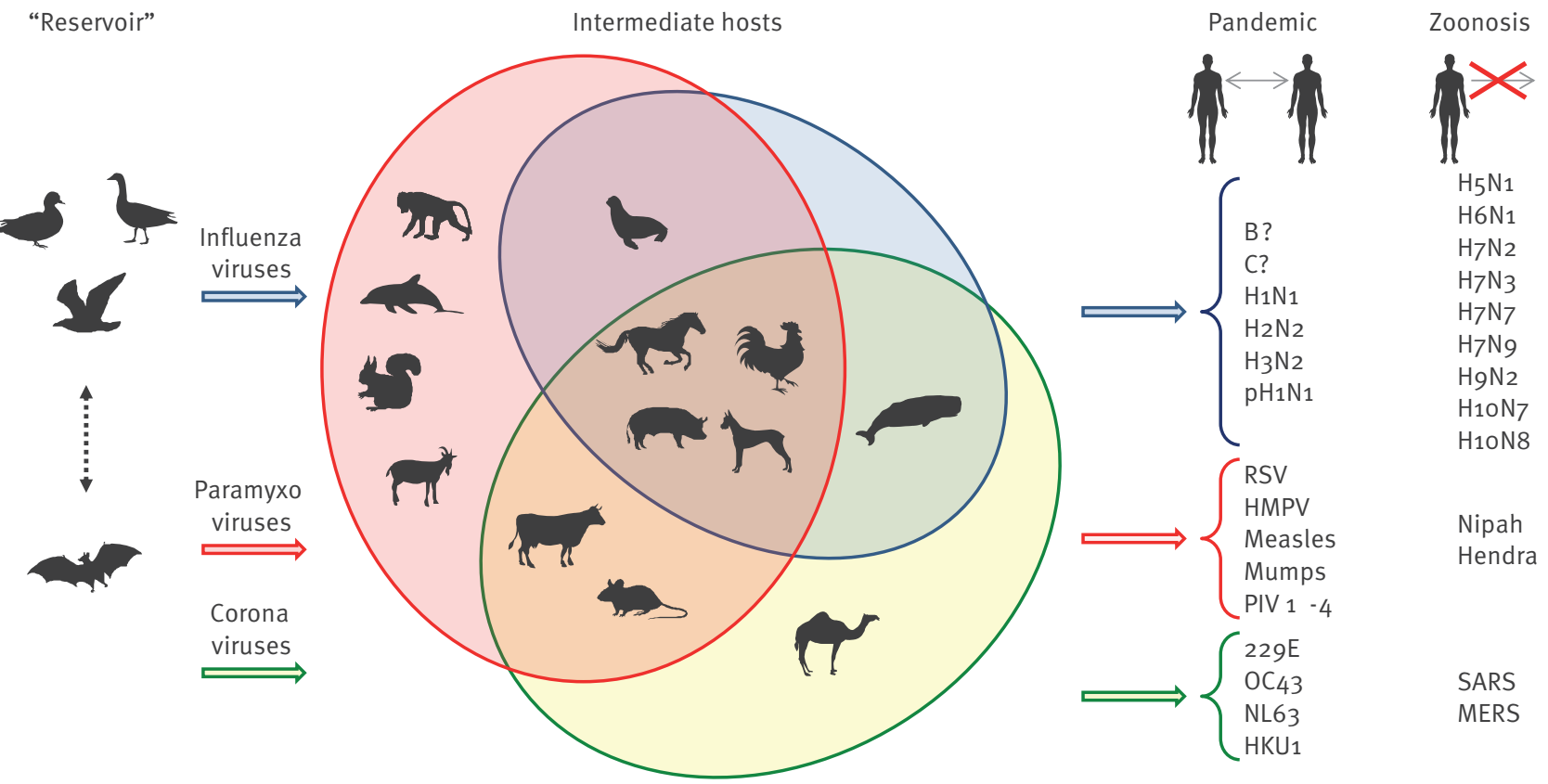

HMPV: human metapneumovirus; MERS: Middle-East respiratory syndrome; PIV: parainfluenza virus; RSV: respiratory syncytial virus; SARS: severe acute respiratory syndrome.

Blue: influenza viruses, red: paramyxoviruses, green: coronaviruses. Dotted arrow: The presence of influenza viruses in both species suggests that transmission from birds to bats, or the other way around, may have occurred in the past.

As humans do not frequently come into contact with bats and wild birds, they are more likely to contract zoonotic viruses via intermediate hosts such as domestic birds and mammals. Such zoonotic events almost always result in isolated cases of human infection, as indicated under 'zoonosis'. Rarely, upon mutation or reassortment, these zoonotic viruses adapt to the new human host, acquire human-to-human transmissibility, and may start a pandemic (as depicted under 'pandemic'). In the last century alone, four human influenza pandemics have occurred. Pandemics of paramyxoviruses and coronaviruses are even more rare, yet numerous viruses of animal origin that belong to these families are also endemic in humans 
respiratory syndrome (MERS) coronavirus. While these zoonotic viruses often caused severe disease and deaths in humans, they generally did not represent global health threats as the viruses lacked the ability of sustained human-to-human transmission. However, some of these viruses might adapt to replicate in and spread between humans, to cause pandemics. This is true in particular for respiratory viruses associated with recent zoonotic outbreaks that belong to families that also contain viruses that are endemic in humans and thus have been shown to possess pandemic potential in the past (Figure). Monitoring and predicting which of the various zoonotic viruses have the potential to cross the species barrier and emerge in humans globally has become a major topic in infectious disease research.

Wildlife can host an enormous diversity of viruses, which generally do not cause severe disease in these reservoir hosts. Bats have been recognised as reservoir hosts of viruses of the Filoviridae, Paramyxoviridae, and Coronaviridae families [2,3], while wild birds harbour the greatest diversity of influenza A viruses. Recently, close relatives of avian influenza $A$ virus were also found in bats [4]. Occasionally, viruses are transmitted from their reservoir hosts to other animal species, intermediate hosts, from which the viruses may subsequently be more efficiently transmitted to humans, e.g. as a consequence of more frequent contact. Unfortunately, very little is known about the genetic and phenotypic viral and host traits that facilitate interspecies transmission. In addition, knowledge on the mechanisms by which these zoonotic viruses may subsequently adapt to efficient replication and spread in humans is lacking. Recently, progress has been made towards understanding the genetic and phenotypic requirements of avian influenza viruses to become transmissible in ferrets [5-9].

Influenza A viruses are among the most intensively studied viruses when it comes to host range and transmission. The reason is that influenza $A$ virus zoonoses and pandemics occur relatively frequently compared with other virus families. Influenza A viruses have been isolated from many hosts, but wild birds in the orders Anseriformes (ducks, geese and swans) and Charadriiformes (gulls, terns and waders) as well as bats are thought to form the virus reservoirs in nature (Figure). At least 18 subtypes of the influenza virus surface glycoprotein haemagglutinin (HA or $\mathrm{H}$ ) and 11 subtypes of neuraminidase (NA or N) have been detected in the reservoirs [4]. In the last century, only influenza A viruses of subtypes $\mathrm{H}_{1} \mathrm{~N}_{1}$ (in 1918 and 2009), $\mathrm{H}_{2} \mathrm{~N}_{2}$ (1957), and $\mathrm{H}_{3} \mathrm{~N}_{2}$ (1968) have spilled over from wild birds to poultry or pigs and subsequently triggered a pandemic, with or without the requirement for prior host adaptation or reassortment (i.e. genetic mixing of gene segments). However, avian influenza viruses circulating in poultry (e.g. of subtypes $\mathrm{H}_{5}, \mathrm{H}_{6}, \mathrm{H}_{7}, \mathrm{H}_{9}$, and $\mathrm{H}_{10}$ ) have occasionally crossed the species barrier to infect humans, raising concerns of a new pandemic threat. The continuing circulation of highly pathogenic avian influenza (HPAI) $\mathrm{H}_{5} \mathrm{~N}_{1}$ viruses in poultry in Asia and the Middle East has resulted in hundreds of millions of poultry deaths. Cross-species transmission events of $\mathrm{H}_{5} \mathrm{~N}_{1}$ virus have been reported for several species of wild birds and mammals, including humans (Figure). However, sustained human-to-human transmission has not yet been described.

A study that appears in the current issue of Eurosurveillance by Chea and colleagues investigated two cases of human influenza $\mathrm{A}\left(\mathrm{H}_{5} \mathrm{~N}_{1}\right)$ virus infection in Cambodia [10]. After the post-mortem diagnosis of influenza $A\left(\mathrm{H}_{5} \mathrm{~N}_{1}\right)$ virus infection in a mother and her child, the authors performed a follow-up study of individuals who had been in contact with the two cases. The mother and child were assumed to have been infected from a common poultry source. Although there were no poultry samples available for retrospective laboratory confirmation of $\mathrm{H}_{5} \mathrm{~N}_{1}$ virus infection, poultry in and around the household had started to die before disease onset of the cases. Respiratory specimens from all contact cases tested negative by RT-PCR for influenza $A\left(\mathrm{H}_{5} \mathrm{~N}_{1}\right)$ virus, and no $\mathrm{H}_{5} \mathrm{~N}_{1}$ antibodies were detected in follow-up sera of contacts. Based on this extensive epidemiological investigation, there was no evidence of human-to-human transmission between the cases or their contacts. The authors conclude that the two cases were most probably exposed to a common source of contaminated environment.

Similar clinical, virological, and epidemiological investigations were performed by Xiao et al. [11] and $\mathrm{Hu}$ et al. [12], but for laboratory-confirmed cases of infection with influenza $\mathrm{A}\left(\mathrm{H}_{7} \mathrm{~N} 9\right)$ virus. Since the emergence of the $\mathrm{H}_{7} \mathrm{~N} 9$ virus in February 2013, only one possible human-to-human transmission event had been described [13]. Here, Xiao and colleagues describe the probable transmission of $\mathrm{H}_{7} \mathrm{~N} 9$ virus from a father to his five year-old child after he worked on a wet market contaminated with $\mathrm{H}_{7} \mathrm{~N} 9$ virus [11]. Disease onset in the child was 10 days later than in the father, and virus was detected in the child several days later as well. The child reportedly did not have contact with poultry in the 12 days before onset of the disease. Investigations of 40 close contacts did not result in the detection of additional cases of infection. Hu et al. describe a similar case of human-to-human transmission from a woman who also contracted influenza $\mathrm{A}\left(\mathrm{H}_{7} \mathrm{~N}\right.$ ) $)$ virus at a contaminated wet market and probably transmitted the virus to her husband [12]. The man reportedly never visited wet markets and had not purchased or eaten poultry in the two weeks before the onset of his illness. Onset of disease and detection of the virus in the man occurred approximately one week later than in his wife. Again, 27 close contacts were followed up, but they all turned out to be $\mathrm{H}_{7} \mathrm{~N} 9$-negative. These studies thus present two probable cases of human-to-human transmission of $\mathrm{H}_{7} \mathrm{~N} 9$ virus. In both studies, high nucleotide sequence identity between the viruses from the linked patients was in agreement with this assumption. In the first study, the virus could further be linked 
genetically to an environmental sample [11]. Although the $\mathrm{H}_{7} \mathrm{~N} 9$ virus has been shown to have some ability of airborne transmission (via aerosol and respiratory droplets) between ferrets [14-18], the human cases are most likely to have occurred through direct contact transmission between family members.

Qi et al. describe the potential origin and genetic diversity of the most recently identified zoonotic influenza

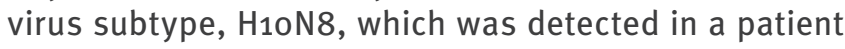
that visited a poultry market a few days before onset of illness [19]. Phylogenetic analysis of the viruses isolated from the patient and the poultry market showed that six genes had the same genetic origin, but the PB1 and $\mathrm{PB} 2$ genes (that are part of the viral polymerase complex) were of a different origin. These two genes from the human and chicken virus may be derived from $\mathrm{H}_{9} \mathrm{~N}_{2}$ chicken and $\mathrm{H}_{7}$ duck influenza viruses, respectively. The genetic differences between the internal genes of the human and chicken viruses suggest that H10N8 viruses continue to undergo reassortment, as reported previously for $\mathrm{H}_{7} \mathrm{~N}_{9}$ virus. The authors suggest that the $\mathrm{H} 10 \mathrm{~N} 8$ viruses have become established in poultry and speculate that the diversity of the $\mathrm{H}_{10} \mathrm{~N} 8$ viruses may be much higher than reported so far.

Interestingly, the $\mathrm{PB}_{2}$ gene of the human $\mathrm{H}_{10} \mathrm{~N} 8$ virus contained an E627K mutation, which is a well-known mammalian adaptation mutation associated with virulence and transmission of influenza viruses in mammals, and which was absent in the avian $\mathrm{H}_{10} \mathrm{~N} 8$ strain. This same mutation was also noted in a fifth paper on influenza virus zoonosis in this issue of Eurosurveillance by Wang et al. [20]. Based on analyses of large numbers of full virus genome sequences, these authors propose an evolutionary history of $\mathrm{H}_{7} \mathrm{~N} 9$ viruses, involving continuous amino acid substitutions and reassortment events. According to the authors, reassortment events resulted in at least 26 genotypes. Additional host adaptation of $\mathrm{H} 7 \mathrm{~N} 9$ viruses resulted in the deletion of five amino acid residues from the NA stalk region and changes in the receptor binding site, resulting in increased affinity for human-type receptors. Finally, the well-known mammalian adaptation mutations in the polymerase complex protein PB2 were acquired, which may allow the viruses to replicate more efficiently in the upper respiratory tract of mammalian hosts. The authors conclude that due to this host adaptation process, the pandemic potential of influenza $A\left(\mathrm{H}_{7} \mathrm{~N} 9\right)$ is higher than that of any other known avian influenza virus. However, it should be noted that the pandemic risk of influenza virus strains may not be equal to their zoonotic risk, and that different influenza virus subtypes or lineages may require different genetic or phenotypic changes to cause zoonoses and pandemics.

Recently, the United States Centers for Disease Control and Prevention developed an inventory of amino acid substitutions in $\mathrm{H}_{5} \mathrm{~N}_{1}$ viruses linked to critical phenotypic changes. It supports a molecular approach for surveillance and is useful for identifying genetic changes that may affect phenotypic traits of importance such as virulence, (mammalian) host adaptation, polymerase activity, airborne transmissibility etc. [21]. In geographical locations where viruses already have some of the critical mutations associated with mammalian adaptation and transmission, intensified surveillance is key for monitoring the emergence of viruses with potentially high impact. As previously described by Russell et al., deep sequencing of avian, other nonhuman, and human virus samples, preferably collected at multiple time points, is necessary to better characterise the likelihood of emergence of viruses with an increased public health risk [22]. Additional studies are also needed to better link the genetic changes in influenza viruses of various subtypes with the phenotypic changes that affect within-host fitness and betweenhost transmissibility. Furthermore, additional experiments are needed to determine the effect of mutations that may affect transmission of newly emerging influenza virus subtypes in humans [22]. Because many substitutions may be functionally equivalent to those described previously, and because the effect of such substitutions may be dependent on the virus backbone, sequence-based virus surveillance alone may be misleading. Therefore, surveillance studies and epidemiological investigations may be improved further by including virus phenotyping assays, using relatively simple methods as described previously for airborne transmissible $\mathrm{H}_{5} \mathrm{~N}_{1}[5]$.

The five publications in the current issue of Eurosurveillance on the potential transmissibility and evolution of influenza viruses highlight the impact of these zoonotic viruses on global health. Surprisingly little is known about the routes and mechanisms of virus transmission. As a consequence of these knowledge gaps, key questions in public health such as "Can newly emerging viruses acquire the ability of human-to-human transmission to trigger a pandemic?" remain unanswered. Increased knowledge is important to predict risks and to adapt pharmaceutical and non-pharmaceutical intervention strategies to prevent outbreaks or pandemics. Currently, we appear to rely on humans as sentinels for virus outbreaks in animals and often apply a reactive rather than pro-active approach to limit the impact of emerging virus infections. Implementation of the One Health concept as an approach to overcome some of the difficulties, including efforts to improve laboratory capacity and surveillance systems in humans and animals, may limit the impact of zoonotic and pandemic threats in the future.

Conflict of interest

None declared

Authors' contributions

Sander Herfst and Ron Fouchier wrote the manuscript. 


\section{References}

1. Taylor LH, Latham SM, Woolhouse ME. Risk factors for human disease emergence. Philos Trans R Soc Lond B Biol Sci. 2001;356(1311):983-9.

http://dx.doi.org/10.1098/rstb.2001.0888

PMid:11516376 PMCid:PMC1088493

2. Drexler JF, Corman VM, Müller MA, Maganga GD, Vallo P, Binger $\mathrm{T}$, et al. Bats host major mammalian paramyxoviruses. Nat Commun. 2012;3:796.

http://dx.doi.org/10.1038/ncomms1796

PMid:22531181 PMCid:PMC3343228

3. Vijaykrishna D, Smith GJ, Zhang JX, Peiris JS, Chen H, Guan Y. Evolutionary insights into the ecology of coronaviruses. J Virol. 2007;81(8):4012-20.

http://dx.doi.org/10.1128/JVI.02605-06 PMid:17267506 PMCid:PMC1866124

4. Tong S, Zhu X, Li Y, Shi M, Zhang J, Bourgeois M, et al. New world bats harbor diverse influenza A viruses. PLoS Pathog. 2013;9(10):e1003657.

http://dx.doi.org/10.1371/journal.ppat.1003657 PMid:24130481 PMCid:PMC3794996

5. Linster M, van Boheemen S, de Graaf M, Schrauwen EJ, Lexmond P, Manz B, et al. Identification, characterization, and natural selection of mutations driving airborne transmission of A/H5N1 virus. Cell. 2014;157(2):329-39. http://dx.doi.org/10.1016/j.cell.2014.02.040 PMid:24725402

6. Sutton TC, Obadan A, Lavigne J, Chen H, Li W, Perez DR. Genome rearrangement of influenza virus for anti-viral drug screening. Virus Res. 2014;189C:14-23. http://dx.doi.org/10.1016/j.virusres.2014.05.003 PMid:24833536

7. Herfst S, Schrauwen EJ, Linster M, Chutinimitkul S, de Wit E, Munster VJ, et al. Airborne transmission of influenza A/ $\mathrm{H}_{5} \mathrm{~N}_{1}$ virus between ferrets. Science. 2012;336(6088):1534-41. http://dx.doi.org/10.1126/science.1213362 PMid:22723413

8. Imai M, Watanabe T, Hatta M, Das SC, Ozawa M, Shinya K, et al. Experimental adaptation of an influenza $\mathrm{H}_{5} \mathrm{HA}_{\text {confers }}$ respiratory droplet transmission to a reassortant $\mathrm{H}_{5} \mathrm{HA}_{/} \mathrm{H}_{1} \mathrm{~N}_{1}$ virus in ferrets. Nature. 2012;486(7403):420-8. PMid:22722205 PMCid:PMC3388103

9. Chen LM, Blixt O, Stevens J, Lipatov AS, Davis CT, Collins BE, et al. In vitro evolution of $\mathrm{H}_{5} \mathrm{~N}_{1}$ avian influenza virus toward human-type receptor specificity. Virology. 2012;422(1):105-13. http://dx.doi.org/10.1016/j.virol.2011.10.006 PMid:22056389

10. Chea N, Yi SD, Rith S, Seng H, leng V, Penh C, et al. Two clustered cases of confirmed influenza $A\left(\mathrm{H}_{5} \mathrm{~N}_{1}\right)$ virus infection, Cambodia, 2011. Euro Surveill. 2014;19(25): $\mathrm{pii}=20839$.

11. Xiao XC, Li KB, Chen ZQ, Di B, Yang ZC, Yuan J, et al. Transmission of avian influenza $A\left(\mathrm{H}_{7} \mathrm{~N} 9\right)$ virus from father to child: a report of limited person-to-person transmission, Guangzhou, China, January 2014. Euro Surveill. 2014;19(25): $\mathrm{pii}=20837$.

12. Hu J, Zhu Y, Zhao B, Li J, Liu L, Gu K, et al. Limited humanto-human transmission of avian influenza A ( $77 \mathrm{Ng})$ virus, Shanghai, China, March to April 2013. Euro Surveill. 2014;19(25): $\mathrm{pii}=20838$.

13. Qi X, Qian YH, Bao CJ, Guo XL, Cui LB, Tang FY, et al. Probable person to person transmission of novel avian influenza $\mathrm{A}\left(\mathrm{H}_{7} \mathrm{~N} 9\right)$ virus in Eastern China, 2013: epidemiological investigation. BMJ. 2013;347:f4752. http://dx.doi.org/10.1136/bmj.f4752 PMid:23920350 PMCid:PMC3805478

14. Watanabe T, Kiso M, Fukuyama S, Nakajima N, Imai M, Yamada $\mathrm{S}$, et al. Characterization of $\mathrm{H}_{7} \mathrm{~N} 9$ influenza $\mathrm{A}$ viruses isolated from humans. Nature. 2013;501(7468):551-5.

http://dx.doi.org/10.1038/nature12392 PMid:23842494 PMCid:PMC3891892

15. Richard M, Schrauwen EJ, de Graaf M, Bestebroer TM, Spronken MI, van Boheemen S, et al. Limited airborne transmission of $\mathrm{H}_{7} \mathrm{Ng}$ influenza A virus between ferrets. Nature. 2013;501(7468):560-3.

http://dx.doi.org/10.1038/nature12476

PMid:23925116 PMCid:PMC3819191

16. Belser JA, Gustin KM, Pearce MB, Maines TR, Zeng H, Pappas $C$, et al. Pathogenesis and transmission of avian influenza $A$ (H7N9) virus in ferrets and mice. Nature. 2013(7468);501:556-9. http://dx.doi.org/10.1038/nature12391 PMid:23842497

17. Zhang Q, Shi J, Deng G, Guo J, Zeng C, He X, et al. H7N9 influenza viruses are transmissible in ferrets by respiratory droplet. Science. 2013;341(6144):410-4. http://dx.doi.org/10.1126/science.1240532 PMid:23868922
18. Zhu H, Wang D, Kelvin DJ, Li L, Zheng Z, Yoon SW, et al. Infectivity, transmission, and pathology of humanisolated $\mathrm{H}_{7} \mathrm{~N} 9$ influenza virus in ferrets and pigs. Science. 2013;341(6142):183-6.

http://dx.doi.org/10.1126/science.1239844

PMid:23704376

19. Qi W, Zhou X, Shi W, Huang L, Xia W, Liu D, et al. Genesis of the novel human-infecting influenza $A\left(\mathrm{H}_{10} \mathrm{~N} 8\right)$ virus and potential genetic diversity of the virus in poultry, China. Euro Surveill. 2014;19(25):pii=20841.

20. Wang D, Yang L, Gao R, Zhang X, Tan Y, Wu A, et al. Genetic tuning of the novel avian influenza $A\left(\mathrm{H}_{7} \mathrm{Ng}\right.$ ) virus during interspecies transmission, China, 2013

21. Centers for Disease Control and Prevention (CDC). $\mathrm{H}_{5} \mathrm{~N}_{1}$ genetic changes inventory: a tool for influenza surveillance and preparedness. Atlanta: CDC; 2012. Available from: http://www. cdc.gov/flu/pdf/avianflu/h5n1-inventory.pdf

22. Russell CA, Fonville JM, Brown AE, Burke DF, Smith DL, James $\mathrm{SL}$, et al. The potential for respiratory droplet-transmissible A/ $\mathrm{H}_{5} \mathrm{~N}_{1}$ influenza virus to evolve in a mammalian host. Science. 2012;336(6088):1541-7.

http://dx.doi.org/10.1126/science.1222526

PMid:22723414 PMCid:PMC3426314 